\title{
THE EVENT-CANCELLING SEMANTICS OF THE ENGLISH ASPECTUALIZER START AND ITS SERBIAN EQUIVALENT KRENUTI
}

The paper revisits the issue of semantic equivalency of two aspectual verbs, start and krenuti, which is proposed by Milivojević (2021a, 2021b). The present analysis focuses on the causative and dynamic semantic features of start and krenuti, with the aim of a contrastive analysis of the aspectual constructions headed by these two verbs. It is shown that both start and krenuti, provided that the necessary linguistic conditions are met, have the ability to "cancel" the event initiated via constructional phase modification. The conditions for such event-cancelling result from the lexical semantics of start and krenuti, as well as from the semantic co-composition on the level of the aspectual construction as a whole. The theoretical frame of the analysis is the presupposition and consequence account by A. Freed (1979). The contrastive analysis and presented theoretical conclusions are backed by a parallel corpus of 200 English and Serbian sentences compiled from the Corpus of Global Web-Based English (GlowBE 2013) and the Corpus of Contemporary Serbian Language (SrpKor 2013).

Keywords: aspectualizers, aspectual constructions, aspectual event, temporal structure, presupposition and consequence, event-cancelling

\section{INTRODUCTION}

As a specific semantic class, phase or aspectual verbs (also called aspectualizers), which by definition are complement-taking verb heads, denote the "initiation, termination, or continuation of an activity" (Levin 1993:274). These verbs describe the temporal segment resulting from the temporal structure of an event which is, in turn, additionally determined by the aspectual interaction between the head verb and its complement. The meaning expressed by the aspectualizers and their complements is therefore understood as semantic co-composition ${ }^{1,2}$ realized at

*natasa.milivojevic@ff.uns.ac.rs

${ }^{1}$ The term is used in the sense of the Generative Lexicon (Pustejovsky, 1995). 
the level of the aspectual construction as a whole. Nagy (2016: 84) appropriately points out that this kind of theoretical analysis is closely in line with the important outlines of construction grammar ${ }^{3,4}$. Aspectualizers, along with their complements have so far received a significant amount of attention in the grounding and subsequent relevant literature in English and Serbian respectively (Antonić, 2000; Brinton, 1988; Dowty, 1977; Duffley 1999, 2006; Freed, 1979; Ivić, 1983; Mair, 1990; Levin, 1993; Milivojević 2021a, 2021b; Mrazović\&Vukadinović, 1990; Nagy, 2009, 2016; Newmeyer, 1975; Perlmutter, 1978; Piper et al., 2005; Pustejovsky, 1995 among others), yet the number of contrastive studies is still relatively small. What is more, certain issues in the behaviour of aspectual verbs remain unaccounted for in the literature; one such open question is the phenomenon of aspectual event-cancellation. As Duffley (1999:297) reports, the specific problem of "why it is that the aspectual construction 'start to $V$ ' can be used both in cases where the event was or was not initiated, whereas 'begin to $V$ ' always implies initiation" still has not been completely answered for English. The present contrastive analysis is an attempt intended as a contribution to this area of linguistic research. We propose a detailed contrastive account of lexical and constructional semantics of two aspectual verbs, i.e. the English aspectualizer start and its Serbian equivalent krenuti with special focus to their event-initiation and event-cancellation semantics, both on the lexical level and on the level of the construction.

2 According to Milivojević (2016: 59) "co-composition is the cover term for syntaxsemantics interface; this is the process of mapping meaning onto structure whereby the head and the complement influence each other through a number of typeshifts and coercions."

${ }^{3}$ Goldberg (2009) views any natural language as a repertoire of more or less complex patterns, i.e. constructions that integrate form and meaning in a conventionalized, noncompositional ways. In other words, a natural language is a continuum of constructions which result from deep-structure projections of argument structure.

4 Aspectualizers are not considered to determine the overall semantics of an aspectual construction in its entirety, since the meaning of aspectual complementation results from the integration of the meaning and function of the aspectual verb into the semantics of the full aspectual construction. We further agree with Nagy in her claim that a difference in form more often than not signals a difference in meaning, therefore different types of complementation with the same aspectual verbs will convey different meanings, or at least additional, subtle shades of the existing meanings. 
The research presented in the paper was filtered through corpus data. The corpus of the present research was compiled from the Corpus of Global Web-Based English (GlowBE 2013) and the Corpus of Contemporary Serbian Language (SrpKor 2013). It contains 200 sentences in total, 100 sentences in English and 100 sentences in Serbian. The primary criteria for the selection of corpus examples were: 1) that the sentence includes one of the two aspectual verbs under analysis and/or 2) that the aspectual construction appears in a complex sentence where the aspectual proposition is coordinated with the event-cancelling clause.

\section{THEORETICAL FRAMEWORK}

The dominant theoretical framework for the present analysis is the presupposition and consequence theory proposed by Alice F. Freed (Freed, 1979). Freed introduces a specified temporal structure of a prototypical aspectual event that may consist of an onset, nucleus and coda.,

Within her theoretical model of aspectual analysis, Freed introduces the terms presupposition and consequence, stating that phase verbs generally trigger an obligatory presupposition ${ }^{7}$. Similar theoretical claim is made in the relevant literature in Serbian. According to Piper et al. (2005: 313) presupposition is part of semantics of the aspectual verb which is obligatory and cannot be altered by negation. For example, when aspectualizers begin and start in English are contrasted, the semantic difference between them is generally explained by the more complex semantic value of start as compared to begin; A. Freed (1979) states that the essential semantic difference between begin and start lies in the fact that start refers to the onset of an event, while begin invariably modifies the first temporal segment of the nucleus. Although the two aspectualizers have similar semantic presuppositions since they both presuppose the initiation of an event,

\footnotetext{
${ }^{5}$ The onset is a temporal segment prior to the nucleus of an event, i.e. the moment before the event is actually initiated; the nucleus is the time segment during which the activity is in progress and coda is the finishing segment which brings an event to its close.

${ }^{6}$ For an extensive discussion on Freed's theory and its implementation to Serbian see Kljakić, 2020 .

7 This generally means that sentences and propositions containing phase verbs have predictable presuppositions and consequences. Freed defines presupposition as specific prior knowledge shared by the speaker and the hearer, and consequence is what the hearer learns after the utterance is stated in a particular linguistic context.
} 
begin and start have different consequence relations; while begin always entails a subsequent occurrence of the event, start may also entail non-occurrence or eventcancellation:

1. Barbara started/*began to study for her exams last week but then she didn't do any studying. (Freed 1979:71) ${ }^{8}$

In the examples below, not the nucleus activity of the event named in the complement but only the onset of this event had taken place. The sentence with phase verb begin cannot have such interpretation. It is therefore plausible to suggest that in terms of phase marking starting is prior to beginning, hence the difference in the grammaticality of the examples in (2a) and (2b):

2. a) She *began to sing (but didn't).

b) She started to sing (but didn't).

The idea of the aspectual verb start marking only the onset of the aspectual event is not new, and it has been noted in the relevant literature. Nagy (2016) reports the following:

The fact that start refers to the onset, the very beginning of a situation, and begin to the first temporal phase of the nucleus... is pointed out by Wierzbicka (1988). Wierzbicka notes that start refers to the first part and begin to the first moment of an event, which, in her opinion, is also shown by the fact that at races and similar events the initial moment is usually called "start" rather than "begin". (Nagy 2009: 97)

If we turn to Serbian, we see that similar situation exists with the pair of aspectualizers početi and krenuti. The difference in behavior of these two verbs is shown in the examples (3a) and (3b) below:

3. a) *Počela je da peva, ali nije zapevala.

b) Krenula je da peva, ali nije zapevala.

\footnotetext{
${ }^{8}$ The sources for the sentential examples are consistently cited in the paper; the examples which lack the source citation were proposed by the author of the paper.
} 
In the example (3a), početi behaves like begin: the non-occurrence of the event cannot be expressed with početi since the event is already in progress, while the example (3b) is fully acceptable in Serbian. This again leads to a conclusion that, just like in English, there is a difference in the time interval of the event which gets modified by the aspectual verb - since krenuti allows for the cancellation of the event, it seems to behave exactly like the English aspectual verb start, so we may conclude that in terms of temporal structure and semantic precedence, krenuti is prior to početi. Furthermore, based on the equivalent argument structures on the syntactic level ${ }^{9}$, Milivojević (2021b) concludes:

Although begin and start are close synonyms in English while početi and krenuti are close synonyms in Serbian, the true overall linguistic equivalent of begin is početi, and the true overall linguistic equivalent of start is krenuti since only these contrastive pairs of aspectualizers project the same type of arguments in the contrastive perspective.“(Milivojević 2021b: page 9, para 2).

The present analysis, however, shifts its focus away from the lexicalprojectionist approach of Levin (1993) and Milivojević (2021b). While we revisit the issue of equivalency of the aspectual pair start and krenuti, the present analysis more closely investigates the aspects of "additional" semantic features of the two verbs, i.e. causality and dynamicity, with the primary aim of explaining eventinitiation and event cancellation phenomena illustrated in the above examples (1-3).

\section{THE “ADDITIONAL” SEMANTICS OF ASPECTUAL VERBS START AND KRENUTI}

Apart from the ability to modify only the onset of the event expressed in the complement when they are used as aspectual verbs, start and krenuti also behave as full lexical verbs. When used as lexical verbs, they denote motion in space and/or physical movement, which makes them semantically close to dynamic motion verbs $^{10}$. The dynamic meaning of start is also listed in WordNet (4), whereas

${ }^{9}$ Start and krenuti both allow for a full range of the available (clausal and nominal) aspectual complements in English and Serbian. For full discussions see Freed, 1979; Kljakić, 2020; Levin, 1993; Milivojević, 2021a, 2021b; Nagy, 2009, 2016.

${ }^{10}$ Duffley (1999) reports on another sense unique to the use of start, and that is the sense of sudden movement as a result of surprise or fear, e.g. She put the bottle on the coffee table beside him, banging it down hard. He started at the sound, his concentration broken. (Duffley, 1999:314) 
Rečnik srpskohrvatskoga književnog jezika (RSKJ) lists the dynamic, motion meaning for the lexical verb krenuti in Serbian (5):

4. START (v) start, go, get going (begin or set in motion): I start at eight in the morning, ready, set, go!"

5. KRENUTI (v.) (neprel.) poći, uputiti se: Već samim jutrom krenusmo naprijed; Kada krenu vode otud sa planine, dojezdiće opet mirno proljeće.

Like the lexical verbs, aspectualizers start and krenuti are also marked for dynamicity, while their aspectual denotation frequently conflates with motion meaning (c.f. Antonić, 2000; Duffley 1999, 2006; Freed, 1979; Levin, 1993; Milivojević 2021a, 2021b; Nagy, 2009, 2016; Piper et al., 2005; Pustejovsky, 1995.) Due to its dynamic lexical semantics, start as an aspectualizer in English frequently combines with dynamic complements, especially with dynamic achievements and activities. We return to this issue in more detail in section 4 of the paper.

It is important to note at this point that phase verb krenuti belongs to the group of secondary or "atypical" aspectualizers in Serbian (c.f. Antonić, 2000; Krstić, 2016; Milivojević, 2021a, 2021b; Piper et al., 2005 among others ${ }^{11}$. Krenuti is primarily a lexical verb which denotes motion in space, but which expresses additional aspectual (and modal) ${ }^{12}$ meanings when it is used as a complementtaking verb. Serbian aspectual constructions constitute of decomposed predicates, with phase matrix verbs. Krstić (2016: 15) stresses the fact that secondary or "atypical" phase verbs, semantically stem from full, lexical verbs with weakened lexical meaning, where the result of such semantic change also influences lexical and grammatical relations on the syntactic level. It is therefore plausible to claim that aspectual verb krenuti indeed contains traces of dynamicity originating from the primary semantics of the lexical verb krenuti.

Next, we turn to causative semantics of the English aspectualizer start. Nagy (2016) and Duffley $(1999,2006)$ report that although both start and begin are marked for causality since they bring about an initiation of the event, start has an additional feature of causality which is missing from begin ${ }^{13}$. The causality feature

\footnotetext{
${ }^{11}$ Other secondary aspectualizers are uzeti i stati. (Piper et.al., 2005: 313)

${ }^{12}$ See Milivojević, 2021a.

${ }^{13}$ Levin (1993) uses the term "causative alternation".
} 
of the verb start, and the absence of such semantic causality in begin is illustrated in the examples (6a) and (6b):

6. a) He started me thinking about the problem.

b) *He began me thinking about the problem.

The reported additional causality is at the interface of semantics and syntax, since it not only attributes an additional feature to the primary lexical semantics of the verb, but is reflected on the level of syntax as well, by adding an additional NP argument to the construction.

Lexicographic sources in Serbian confirm the lexical causality of krenuti. RSKJ lists the following causative meanings for the verb krenuti, where all of these denotations refer to the initiation of the event: staviti u pokret, učiniti da se ko ili što pokrene sa svoga mesta, maknuti, pomaknuti, zaljuljati, isterati, poterati, izazvati, izmamiti. Sentences (7) and (8) are examples of aspectual verb krenuti with causative interpretation, extracted from SrpKor $2013^{14}$ :

7. Uh, kako se oseća zadah ustajale vode koja se ne miče! Davi, guši. Vetra daj da krene nepomičnu trulu masu! Nigde vetrića ... (SrpKor 2013: Domanović, Radoje. Mrtvo more. Izabrane satire.)

8. Ona je dugo ubeđivala da je preko potrebno da se odmah pošalje naročito lice u Petrograd, da krene neku medicinsku znamenitost prvog reda pa da je prvim vozom dovede ovamo. Ali kćeri je odgovoriše. (SrpKor 2013: Dostojevski, Fjodor Mihajlovič. Idiot.)

Having confirmed the additional semantic equivalency of the aspectual verbs start and krenuti with respect to their semantic features of dynamicity and causality, we now turn to discuss the linguistic conditions for event-cancelling in English and Serbian.

\section{THE CONTRASTIVE SEMANTICS OF EVENT-CANCELLING}

\footnotetext{
${ }^{14}$ Some of the listed causatively marked constructions are stylistically marked in Serbian, i.e. they belong to literary style, or are partly obsolete and/or archaic. However, the primary focus of our research is the availability of the construction in Serbian. We leave the closer stylistic analysis of the language data open for future research.
} 
Event-cancelling is primarily a semantic operation which happens on the constructional level. It is caused by the co-composition of linguistic entities and temporal conditions, and just like the integral meaning of the aspectul construction, it comes about at the syntax-semantics interface. To state it more precisely, we consider it as semantic co-composition in the sense of the Generative Lexicon Theory ${ }^{15}$. Freed (1979) generally accounts for the cases of aspectual event's nonoccurrence such as those in the examples $(1-3)^{16}$ by stating that, in English, aspectual start modifies only the onset of the event, which is why, after the onset, the event may not continue into the nucleus. Similar analysis of the semantics and complementation of the phase verb krenuti, which reflects on the implications of Freed's model for Serbian, is offered in Milivojević (2021a, 2021b). Since, as stated above, start is a phase modifier which refers to the initial, integral part of the temporal structure of the aspectual construction, and due to its "immediate" semantics which is marked as causative and dynamic, its meaning frequently allows for various semantic interpretations related to situations with an abrupt start, or a "sudden causing" of the event. Furthermore, start, due to its additional causality,

"can be used in contexts when it refers not only to the temporality of the sentence but to the initiating activity of the event (in the complement) as well. Begin, on the contrary, cannot be used in such contexts, e.g. When are you going to start/*begin the fire? (Nagy, 2016:86)

Contrastively speaking, we argue that both start and krenuti frequently combine with dynamic complements, i.e. semelfactives, achievements and activities $^{17}$ which are connected to sudden action or abrupt motion. In addition to this, example (9) below shows that in English, event-cancelling may be blocked not only by matrix verb semantics, but by the -ing aspectual complement as well:

9. a) She started to cry/*crying, but then she didn't cry. (activity verb)

b) She started to sneeze/*sneezing, but the she didn't sneeze. (semelfactive verb)

Nagy (2016:98) reports that, in English "in contrast to to-infinitive, the -ing construction after aspectual verbs makes reference to a specific event or series of

\footnotetext{
${ }^{15}$ C.f. Pustejovsky, 1995.

${ }^{16}$ Freed's account bears the equivalent implications for Serbian in contrast to English. For detailed discussion, see Kljakić, 2020.

${ }^{17}$ In the sense of Vendler, 1957.
} 
events which can be identified to be simultaneous with the time phrase expressed by the matrix verb." We conclude that such "actuality", i.e. the dynamic reading of the -ing complement blocks the cancelling of the event in the complement in (9). Also, the -ing construction, in terms of temporal structure, represents a non-temporal complement ${ }^{18}$, which cannot be segmented into phases. This means that the onset of the event is not available to the phase verb for modification which further results in blocking of event-cancelling. The equivalent situation is present with nominal (NP) aspectual complements of krenuti in Serbian:

10. a) *Krenula je s plakanjem, ali nije zaplakala.

Serbian aspectualizer krenuti frequently semantically conflates motion, modality and phase when it is used in the aspectual sense. This is accounted for in Milivojević (2021a, 2021b) where the author argues that krenuti in Serbian, apart from the lexical meaning, expresses two additional meanings and those are the aspectual meaning denoting the beginning of the event and modal meaning denoting intention and/or volition. Milivojević (2021b) also claims that regarding the lexical aspect of the complements in internal argument position to the aspectual verb head, krenuti is equivalent to start, as it allows for different dynamic verb situations (activities and semelfactives) in the complement position. Consider (11a) and (11b) below:

11. a) Krenula je da plače, ali nije zaplakala. (activity)

b) Krenula je da zaplače, ali se predomislila. (semelfactive) ${ }^{19}$

Appart from the prototypical instances of event's non-occurence ${ }^{20}$, there are more complex (sub)cases, or atypical cases of event-cancelling in English and

18 This term in the general literature on aspectual analysis as a rule marks the absence of (phase) segmentation of the given structure.

19 Milivojevic (2021b) discusses the issue of the prefixed verbs in the aspectual complements in Serbian, offering arguments for the cases in which the overall construction can be treated as aspectual. Since we are only concerned with the contrastive Aktionsart features of the complements, we do not discuss the issue of perfective complementation here, yet we indicate that, in the cases where prefixed verbs appear in the complement, the prefix primarily marks semelfactive Aktionsart, not the perfective aspect. 
Serbian. Those are the situations where the initiated event which continues after the onset does not develop the expected and/or predefined temporal structure. In such insances, the event is clearly initiated, yet its continuation happens in some kind of altered, incomplete, or unexpected way. To prove that the event-cancelling operation takes place, we propose a test of syntactic coordination. The complex proposition (or the sentence-complex) which contains the aspectual proposition and another coordinated proposition has to be both grammatically (syntactically) and semantically valid:

12. a) Henry started to kick the ball, but stopped.

b) Henry started to sneeze, but sharply coughed instead.

c) ??Henry started to sneeze, but quickly changed his mind.

13. a) Krenuo je da šutne loptu, ali se sapleo.

b) Krenuo je da kine, ali se umesto toga zakašljao.

c) ??Krenuo je da kine, ali se predomislio.

Examples (12a) and (13a) illustrate prototypical event-cancelling cases, while (12b) and (13b) are event-substitutions. Turning to the problematic semantic acceptability of (12c) and (13c), we see that when the coordination test is applied, semantic features such as intentionality, volition, control and so on interfere with the validity of the proposition-complex. As to the question whether start presupposes intentional causality, Dowty (1977) states that it can be marked both for intentional and nonintentional causation, which is in line with Freed (1979) who argues that both begin and start are unspecified regarding the active attempt of the subject, but that an event which is marked for causality does not necessarily presuppose an "intention" interpretation, but rather that there was something or someone which was the cause of the event, e.g. The flowers began/ started to wilt. What the syntactic coordination test proves is that the semantics of the aspectual construction dictates the conditions of event-cancelling. In other words, an involuntary, reflex action like sneezing cannot be cancelled by voluntary counteraction.

${ }^{20}$ For an extensive discussion see Duffley 1999, 2006; Freed, 1979; Nagy 2009, 2016, among others. 
Although examples like $(12 b)^{21}$ are not explicitly accounted for in Freed's proposal, there is space for calculating them into the analysis. Namely, if start refers only to the onset of the complement event, the initiated action may either stop after the onset or it may continue in some kind of altered or unexpected way, subsequently turning into a different action. Before we define the criteria for aspectual event-cancelling based on the present discussion, we briefly turn to discuss Duffley's (1999) account. Duffley disagrees with Freed and argues that start does not modify any segment of the temporal structure event; what start denotes, in his view, is just "breaking out of a state of rest" prior to the initiation of the event.

Due to the fact that start, unlike begin, does not inherently designate a segment of an event, the notion of breaking out of a state of rest or inactivity which it denotes can also be construed merely as a movement towards the first moment of the infinitive's event, in which case the latter will be understood to be non-initiated. (Duffley, 1999: 319)

While this account may generally suffice for the prototypical eventcancellation cases with to-infinitive complements in English, it does not account for situations like (12b). The denotation of start as "breaking out of a state of rest" where this action only precedes another event (or its initiation) in an aspectually unrelated fashion, disregards the causality of start, therefore also excluding the option of the "non-initiated" event to continue. To account for all relevant cases, i.e. (12a) (12b), as well as for the weaker acceptability of (12c) we define the prototypical aspectual event-cancelling situation in English, as constituting an aspectual construction with start combined with a dynamic aspectual complement, especially such whose denotation is connected to sudden or momentary action. In line with this conclusion, we propose that the linguistic condition for eventcancelling with (henceforth LCEC) reads as follows:

The aspectual event can be cancelled if

1) START initiates/causes the complement event,

2) START modifies only the onset of the complement event

3) START and the complement event are dynamic

In addition to the primary LCEC requirements, the test of syntactic coordinaton may be used to test the semantic validity of the proposition-complex.

\footnotetext{
${ }^{21}$ Subsequently also for (13b) in the contrastive perspective, i.e. if Freed's model is applied to Serbian.
} 
The prototypical event-cancelling situation in Serbian, like in English, constitutes an aspectual construction with krenuti combined with a dynamic aspectual complement, especially such whose denotation is connected to dynamic Aktionsart (e.g. dynamic acitivities or achievements) Additionally, in prototypical cases krenuti conflates phase, causality and motion denotation in such a way that its meaning can be paraphrased as "physically start to initiate the event", with motion in space or physical movement evident at the time of the utterance (13a-b).

In addition to the previously discussed prototypical event-cancelling situations, examples (14-19) illustrate additional, atypical event-cancelling aspectual constructions, i.e. event-substitution constructions with start and krenuti extracted from GlowBE and SrpKor, respectively. The LCEC condition applies to these examples in the same manner in which it applies to the prototypical cases, the only difference being in the fact that the actual event-cancelling in the examples below happens not by direct cancellation of the event, but by event-substitution: in other words, the cancellation results in the altered initiated event.

14. After struggling with various engine components for over an hour the thing eventually started but firing on only seven cyllinders. As for the eighth, to hell with it. (GlowBE 2013: https://ntz.info/gen/n01359.html)

15. The excel.exe process got started, but it just stays stuck. (GlowBE 2013: social.msdn.microsoft.com)

16. We started to go home, but we ran out of gas. (GlowBE 2013: https://www.fanfiction.net)

17. A Rebeke nigde. Samo slika kako se zgurila pod njegovom rukom što je bila krenula da je udari, sva trapava i pijana, sećanje na udarac pesnice o frižider. (SrpKor 2013: Grifitis, Nil. Patrljak.)

18. Odjednom se pojavio ispred mog kabineta, ispod jakne izvadio drvenu palicu i krenuo da me udari. Uspeo sam nekako da se zaštitim vratima. (SrpKor 2013: www.rts.rs (27.11.2008.))

19. A kad je voda počela da ključa i da se puši, Monmorensi je to smatrao izazovom. I baš kad bi krenuo da ga napadne, neko od nas bi mu ispred nosa odneo čajnik. Tog dana je odlučio da bude brži. (SrpKor 2013: Džerom, K. Džerom. Tri čoveka u čamcu. ASPAC.)

\section{CONCLUDING REMARKS}

The present contrastive analysis had the primary aim of revisiting the semantic equivalency of the English aspectual verb start and its Serbian equivalent 
krenuti for the purpose of defining the semantic conditions for event-cancelling (LCEC) in aspectual constructions headed by these two verbs. We start from the lexical contrast of start and krenuti, subsequently shifting the focus of the analysis onto the constructional level. We propose that aspectualizers start and krenuti are semantically marked for dynamicity and causality, that both verbs combine with the full range of the available aspectual arguments and both semantically preceede their close synonyms begin and početi - in terms of phase, start is prior to begin and krenuti is prior to početi. Moreover, start and krenuti can both refer only to the onset of the event denoted in the complement. The semantic proposition of the two aspectual verbs is obligatory and cannot be altered under negation. The prototypical event-cancelling situation in Englsih and Serbian constitutes an aspectual construction combined with a dynamic aspectual complement. The established LCAC condition is valid in the contrastive perspective as are all the relevant semantic features of start and krenuti. The theoretical conclusions proposed in this discussion could be tested on larger corpora in English in Serbian - the present research was aimed at the initial theoretical implications, since LCAC so far has not been fully accounted for in the previous relevant approaches. Finally, it should be noted that LCAC implicates a complex syntax-semantics interface, with a significant degree of context integration, and additional pragmatic implications, the issues which we leave open for further research.

Nataša Milivojević

\section{KONTRASTIVNA ANALIZA FAZNIH GLAGOLA START I KRENUTI U KONSTRUKCIJAMA SA SEMANTIČKIM NEGIRANJEM RADNJE}

\section{Sažetak}

Rad se bavi kontrastivnom analizom semantičkih odlika faznih glagola start i krenuti u okviru aspektualne konstrukcije sa semantičkim negiranjem radnje (SNR). Kreće se od leksičkog nivoa analize, gde se uspostavlja ekvivalencija između dve glagolske lekseme, a od posebnog značaja za naše istraživanje su semantička svojstva dinamičnost i kauzalnost koja su ključna za semantičko negiranje radnje na nivou aspektualne konstrukcije u kojoj se fazni glagol start u engleskom, odnosno fazni glagol krenuti u srpskom jeziku nalazi na poziciji upravnog elementa. Prototipska aspektualna konstrukcija na koju je moguće primeniti mehanizam semantičkog negiranja radnje sastoji se od faznog glagola (start/krenuti) i obaveznog aspektualnog komplementa kojim se označava aspektualni događaj, tj. radnja. Naša diskusija potvrđuje da su oba fazna glagola nosioci svojstava dinamičnost i kauzalnost i da oba glagola u okviru aspektualne konstrukcije modifikuju nastup (tj. inicijalnu fazu) glagolskog događaja, što su preduslovi za semantičko negiranje 
radnje. U oba jezika, semantičko negiranje radnje podrazumeva da je i radnja označena komplementom, tj. radnja koja podleže semantičkom negiranju, nosilac dinamičke akcionalnosti. Ova tri preduslova, zajedno sa definisanom prototipskom strukturom konstrukcije neophodna su da bi semantičko negiranje radnje bilo moguće. Budući da se semantičko negiranje radnje odvija u međuodnosu semantike i sintakse, u radu se formulišu sintaksički testovi kojima se proverava gramatičnost i semantička validnost propozicije čija radnja je negirana.

Zaključci prikazani u radu provereni su na paralelnom korpusu od 200 rečeničnih primera kojima su obuhvaćene relevantne kontekstualizacije glagola start i krenuti, a koji su sakupljeni iz dva elektronska korpusa engleskog i srpskog jezika, GlowBE 2013 i SrpKor 2013.

Ključne reči: fazni glagol, fazna konstrukcija, komplement, temporalna struktura, presupozicija i posledica, semantičko negiranje radnje

\section{SOURCES}

GlowBE 2013: Davies, Mark. Corpus of Global Web-Based English (GlowBE): 1.9 billion words from speakers in 20 countries (GloWbE). Available online at https://corpus.byu.edu/glowbe/(Accessed: 1.3.2021).

SrpKor 2013: Vitas, Duško - Utvić, Miloš. „Korpus savremenog srpskog jezika (SrpKor), verzija SrpKor2013“. Grupa za jezičke tehnologije Univerziteta u Beogradu, Available online at http://www.korpus.matf.bg.ac.rs/korpus/ (Accessed: 1.3.2021).

Stevanović, M. -Marković, S. -Matić, S. -Pešikan, M. (ured.) (1967-1976). Rečnik Matice srpske I-VI: Rečnik srpskohrvatskoga književnog jezika. Novi Sad: Matica srpska, Zagreb: Matica hrvatska.

WordNet 1998: Christiane Fellbaum (ed.) WordNet: An Electronic Lexical Database. Cambridge, MA: MIT Press. Available online at https://wordnet.princeton.edu/(Accessed: 1.3.2021).

\section{REFERENCES}

Antonić, I. (2000). Aspekatska vrednost predikacije s faznim/modalnim glagolom na primeru rečenice s temporalnom klauzom. Južnoslovenski filolog, 56 (12), 93-101.

Brinton, L. (1988). The Development of English Aspectual Systems. Cambridge: Cambridge University Press. 
Dowty, D. R. (1977). Toward a Semantic Analysis of Verb Aspect and the English 'Imperfective' Progressive. Linguistics and Philosophy, Vol. 1, Issue 1, 4577.

Duffley, P. J. (1999). The use of the infinitive and the -ing after verbs denoting the beginning, middle and end of an event. Folia Linguistica XXXIII/3-4, 295 331.

Duffley, P. J. (2006). The English gerund-participle in cognitive grammar. Columbia, SC: Hornbeam Press.

Freed, A. (1979). The Semantics of English Aspectual Complementation. Dordrecht: D. Reidel.

Goldberg, A. (2009). Constructions and Semantic Frames. In: Rappaport Hovav, M., E. Doron and I. Sichel (eds.). Syntax, Lexical Semantics and Event Structure. Oxford: Oxford University Press.

Ivić, M. (1983). Lingvistički ogledi. Beograd: Prosveta.

Kljakić, S. (2020). Semantičko-sintaksički međuodnos faznog glagola i komplementa u engleskom i srpskom jeziku - kontrastivni pristup (Nepublikovana doktorska disertacija). Filozofski fakultet, Univerzitet u Novom Sadu, Novi Sad.

Krstić, M. (2016). Leksički krnji glagoli i njihova upotreba u savremenom ruskom i srpskom jeziku (Nepublikovana doktorska disertacija). Filozofski fakultet, Univerzitet u Novom Sadu, Novi Sad.

Levin, B. (1993). English Verb Classes and Alternations: A Preliminary Investigation. Chicago: The University of Chicago Press.

Milivojević, N. (2016). Konstrukcioni idiomi u engleskom i srpskom jeziku. Edisertacija10. Novi Sad: Filozofski fakultet. http://digitalna.ff.uns.ac.rs/ sadrzaj/2016/978-86-6065-384-2

Milivojević, N. (2021a). O analitičkim predikatima sa glaglom krenuti u srpskom jeziku: leksičko-projekcionistički pristup. Srpski jezik, studije srpske $i$ slovenske,26, Naučno društvo za negovanje i proučavanje srpskog jezika, Beograd. (in press)

Milivojević, N. (2021b). A contrastive account of phase verbs begin and start in English and Serbian. Nasleđe, $21^{\text {st }}$ Century English: Theoretical and Applied Perspectives, Kragujevac. (in press)

Mrazović, P.-Vukadinović, Z. (1990). Gramatika srpskog jezika za strance. Sremski Karlovci, Novi Sad: Izdavačka knjižarnica Zorana Stojanovića, Dobra vest. 
Nagy, T. (2009). The Semantics of Aspectualizers in English. (PhD dissertation), Debrecen University

Nagy, T. (2016). On Aspectualizers in English: A Corpus Based Approach. ClujNapoca: Scientia Publishing House.

Mair, C. (1990). Infinitival Complement Clauses in English. Cambridge: Cambridge University Press.

Newmeyer, F., J. (1975). English Aspectual Verbs. The Hague: Mouton.

Perlmutter, D., M. (1970). The two verbs begin. In: Jacobs R., A. and Rosenbaum P., S. (eds.), Readings in English Transformational Grammar. Waltham, MA: Ginn.107-119.

Piper, P.-Antonić, I.-Ružić, V.-Tanasić, S.-Popović, Lj.\&Tošović, B. (2005). Sintaksa savremenoga srpskog jezika, Prosta rečenica. Beograd: Institut za srpski jezik SANU.

Pustejovsky, J. (1995). The Generative Lexicon. Cambridge, MA: MIT Press.

Vendler, Z. (1957). Verbs and Times. The Philosophical Review, 66, 143-160.

Wierzbicka, A. (1988). The Semantics of Grammar. Amsterdam: John Benjamins. 